\title{
BASIC DYESTUFFS REMOVAL FROM TEXTILE EFFLUENTS USING FEATHERS: EQUILIBRIUM, KINETIC AND COLUMN STUDIES
}

\section{J. SOUSA \\ O.M. FREITAS \\ S.A. FIGUEIREDO*}

Received: $20 / 12 / 11$

Accepted: 29/02/12
REQUIMTE / Instituto Superior de Engenharia do Porto

Rua Dr. António Bernardino de Almeida, 431

4200 - 072 Porto - Portugal

*to whom all correspondence should be addressed: e-mail: saf@isep.ipp.pt

\section{ABSTRACT}

This research work has been focused in the study of gallinaceous feathers, a waste that may be valorised as sorbent, to remove the Dark Blue Astrazon 2RN (DBA) from Dystar.

This study was focused on the following aspects: optimization of experimental conditions through factorial design methodology, kinetic studies into a continuous stirred tank adsorber (at $\mathrm{pH} 7$ and $20^{\circ} \mathrm{C}$ ), equilibrium isotherms (at pH 5,7 and 9 at 20 and $45^{\circ} \mathrm{C}$ ) and column studies (at $20^{\circ} \mathrm{C}$, at pH 5 , 7 and 9). In order to evaluate the influence of the presence of other components in the sorption of the dyestuff, all experiments were performed both for the dyestuff in aqueous solution and in real textile effluent.

The pseudo-first and pseudo-second order kinetic models were fitted to the experimental data, being the latter the best fit for the aqueous solution of dyestuff. For the real effluent both models fit the experimental results and there is no statistical difference between them. The Central Composite Design (CCD) was used to evaluate the effects of temperature $\left(15-45^{\circ} \mathrm{C}\right)$ and $\mathrm{pH}(5-9)$ over the sorption in aqueous solution. The influence of $\mathrm{pH}$ was more significant than temperature. The optimal conditions selected were $45^{\circ} \mathrm{C}$ and $\mathrm{pH}$ 9. Both Langmuir and Freundlich models could fit the equilibrium data. In the concentration range studied, the highest sorbent capacity was obtained for the optimal conditions in aqueous solution, which corresponds to a maximum capacity of $47 \pm 4 \mathrm{mg} \mathrm{g}^{-1}$.

The Yoon-Nelson, Thomas and Yan's models fitted well the column experimental data. The highest breakthrough time for $50 \%$ removal, $170 \mathrm{~min}$, was obtained at $\mathrm{pH} 9$ in aqueous solution. The presence of the dyeing agents in the real wastewater decreased the sorption of the dyestuff mostly for $\mathrm{pH} 9$, which is the optimal $\mathrm{pH}$. The effect of $\mathrm{pH}$ is less pronounced in the real effluent than in aqueous solution. This work shows that feathers can be used as sorbent in the treatment of textile wastewaters containing DBA.

KEYWORDS: basic dyes, column, equilibrium, kinetics, low cost materials, sorption, wastewater.

\section{INTRODUCTION}

Textile dyestuffs should be removed from wastewaters because they can cause reduction in the primary production that will affect the aquatic ecosystem, and also for aesthetical reasons. Besides some of them may also be toxic, namely basic dyes (Anliker et al., 1988), which are considered one of the more problematic classes of dyes (El Qada et al., 2008). Their use has been increasing due to the increment of acrylic fibres production (1.4\%) in the last decades, which are dyed using basic (cationic) dyes. The 2002 global production was 2.7 million of metric tons (Fiber Economics Bureau, 2003).

Sorption has been considered as one of the most efficient technologies for colour removal (Crini, 2006). Activated carbon is one of the most widely used adsorbents in textile wastewater treatment. However, this treatment presents high operation costs, due to the high price of the activated carbon and to the high volume of effluent involved. 
In the last decades research has been directed towards alternative sorbents to replace the costly activated carbon. They are considered low-cost sorbents if they require little processing, are abundant in nature or are by-products or waste materials from industry (Bailey et al., 1999). Certain waste products from industrial and agricultural operations, natural materials and biosorbents represent potentially economical alternative sorbents. Many of them have been tested and proposed for dye removal (Crini, 2006; Gupta and Suhas, 2009; Srinivasan and Viraraghavan, 2010).

Feathers are generated in huge quantities as a waste of the commercial poultry processing plants, which poses a disposal problem (Mittal et al., 2007) and may be valorised as sorbent. Gallinaceous feathers were selected as sorbent for the basic dye Dark Blue Astrazon 2RN (from Dystar), which is a poorly biodegradable dyestuff (less than 10\%) and toxic to fish (Dystar, 2002).

This study was focused on the following aspects: optimization of experimental conditions through factorial design methodology, kinetic studies into a continuous stirred tank adsorber, equilibrium isotherms and column studies. In order to evaluate the influence of the presence of other components in the sorption of the dyestuff, all experiments were performed both for the dyestuff in aqueous solution and in real textile effluent.

\section{MATERIALS AND METHODS}

\subsection{Materials}

The basic dyestuff Dark Blue Astrazon 2RN (DBA), kindly supplied by Dystar, is a mixture of two

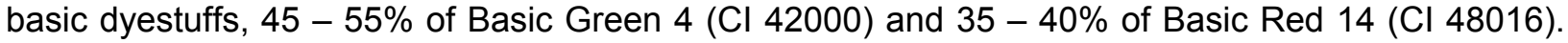
Dyestuff solutions, at $20 \mathrm{ppm}$ concentration, were prepared with distilled water and were boiled for $30 \mathrm{~min}$ for complete dissolution. The real effluent, containing only the selected dyestuff and the auxiliary dyeing agents (Sera Tard A-AS, Evo Soft S-OT, Sera Sperse M-IW, Sera Lube M-UFC and sodium acetate), was also kindly provided by Dystar. The final $\mathrm{pH}$ was adjusted to the desired value with chloridric acid or sodium hydroxide.

Gallinaceous feathers from a local poultry processing industry were used. They were washed with water and detergent, then thoroughly rinsed with water and finally dried in the air at room temperature $\left(20^{\circ} \mathrm{C}\right)$ for several days. Feathers were ground in a knives mill.

\subsection{Methods}

The dyestuff concentration of each sample was obtained by measuring its absorbance in a UV-Vis spectrophotometer (Jenway 6100) at the maximum absorbance wavelength $(518 \mathrm{~nm})$. The $\mathrm{pH}$ values were evaluated using a Consort C862 multiparameter analyser.

Kinetic studies were performed at $\mathrm{pH} 7$ and $20^{\circ} \mathrm{C}$, using $1 \mathrm{~g} \mathrm{~L}^{-1}$ sorbent concentration $(900 \mathrm{~mL}$ of total volume). Magnetic stirring (SBS) at $400 \mathrm{rpm}$ was used and samples were taken during the experiments, along 1 day. $\mathrm{pH}$ was measured continuously. A centrifuge (Sartorius, Sigma 2-16) was used to separate the feathers and then dyestuff concentration was evaluated.

Factorial planning was used to evaluate the effects of temperature $\left(15-45^{\circ} \mathrm{C}\right)$ and $\mathrm{pH}(5-9)$, over the dyestuff sorption in aqueous solution. A set of $100 \mathrm{~mL}$ Erlenmeyers (with cap) containing $50.00 \mathrm{~mL}$ of solution and $0.05 \mathrm{~g}$ of feathers was used. Agitation was performed at $400 \mathrm{rpm}$ using a magnetic stirrer (Velp, Multistirrer 15) into a refrigerated incubator (Lovibond). Replicates and a control test (without sorbent) were made.

Equilibrium isotherms were determined, using the same experimental procedure that was used in factorial design studies, except that different amounts of sorbent were used and no replicates were made. Different experimental conditions were tested for $\mathrm{pH}(5,7$ and 9$)$ and temperature (20 and $\left.45^{\circ} \mathrm{C}\right)$.

Column experiments were performed using a glass column (Omnifit), with $2.5 \mathrm{~cm}$ inside diameter and $15 \mathrm{~cm}$ height column. The dyestuff solution was pumped (Gilson, Miniplus 3 ) downflow at $5 \mathrm{~cm}^{3} \mathrm{~min}^{-1}$ flowrate. After weighing $4 \mathrm{~g}$ of feathers, they were immersed in distilled water and the air in the adsorbent pores was removed by a vacuum pump, to allow a full contact sorbent/dyestuff. Then they were placed inside the column. The average dyestuff concentration used was of $70 \mathrm{mg} \mathrm{L}^{-1}$. Samples were collected at the column outlet, allowing the determination of the dyestuff concentration and $\mathrm{pH}$. 


\section{RESULTS}

This research includes different steps: kinetic studies, optimization of experimental conditions, equilibrium isotherms and column studies. All experiments were performed both for the dyestuff in aqueous solution and in real textile effluent in order to evaluate the influence of the presence of other components in the sorption of the Dark Blue Astrazon 2RN.

The software Fig.P (version 2.98) was used for the non-linear adjustment to models. The statistic treatment allowed the determination of the confidence intervals at $95 \%$ for each parameter of the model, the variance $\left(\mathrm{s}^{2}\right)$ and the determination factor $\left(r^{2}\right)$ for each model. The Fisher's test was used to compare models based on the $F$ value for each model $\left(F_{\text {calc }}\right)$ and $F$ critical value $\left(F_{c}\right)$ for a probability of $95 \%$.

\subsection{Kinetics}

The kinetic studies were performed at $\mathrm{pH} 7$ and $20^{\circ} \mathrm{C}$ both for the dyestuff in aqueous solution and for the real effluent (Figure 1), respectively with initial concentrations of 20 and $73 \mathrm{mg} \mathrm{L}^{-1}$. The equilibrium times obtained were 2 and $3 \mathrm{~h}$, respectively for the dyestuff in aqueous solution and in the real effluent. For convenience a contact period of $24 \mathrm{~h}$ was adopted in further experiments. The $\mathrm{pH}$ showed a slight decreased in the dyestuff aqueous solution (from 7.0 to 6.2) and it had no variation in the textile effluent, which might be explained by the buffer capacity given by the dyeing agents present in the wastewater.

The Lagergren's (1898) pseudo-first and Ho's (1995) pseudo-second order models were fitted to the experimental data. The parameters of the models and their statistics are presented in Table 1. Accordingly to Fisher's test the best fit for the aqueous solution of dyestuff was the pseudo-second order model; both models could fit the experimental results of the real effluent and there was no statistical difference between them, although the pseudo-second order model adjusts better to the shape of the experimental data.

\subsection{Optimization}

The optimization of experimental conditions was performed through factorial design methodology using JMP "The Statistic Software (version 5)". The Central Composite Design (CCD) was used to evaluate the effects of temperature and $\mathrm{pH}$ over the sorption in aqueous solution. They were evaluated at three levels $(-1,0,+1)$ for temperature $\left(15,30,45^{\circ} \mathrm{C}\right)$ and $\mathrm{pH}(5,7,9)$, respectively, which are possible working ranges for this kind of effluent. The analysis of variance (ANOVA) of the quadratic model for dyestuff sorption by feathers show high significance of the model (Table 2) and has a determination factor of 0.946 . The mathematical model that represents the influence of variables, their interactions and the statistics of the regression are presented in Table 3 . The linear effects of $\mathrm{pH}$ and temperature, their interaction and the quadratic effect of temperature are significant, being the influence of $\mathrm{pH}$ more significant than temperature. The optimal conditions selected were $45^{\circ} \mathrm{C}$ and $\mathrm{pH} 9$.

Sorption of the cationic dye DBA is enhanced at higher $\mathrm{pH}$ values. This might be explained by the attraction between the dyestuff (positively charged) and the feathers negatively charged (Mittal, $2006 \mathrm{~b}$ ) when the $\mathrm{pH}$ value of the solution is higher than the point of zero charge (Noh and Schwarz, 1991).

Temperature rise has a favourable effect on adsorption rate, which might be related to swelling of the porous structure of feathers allowing a further penetration of the large dyestuff molecule, as observed in chitin by McKay et al. (1982).

\subsection{Equilibrium}

The equilibrium studies were performed using the optimal conditions, $\mathrm{pH} 9$ and $45^{\circ} \mathrm{C}$. However both the correction of $\mathrm{pH}$ from 5 (the original $\mathrm{pH}$ of the effluent) to 9 (the optimal $\mathrm{pH}$ value) and the warming up of the effluent from $20^{\circ} \mathrm{C}$ (usually the temperature of the effluent) to $45^{\circ} \mathrm{C}$ (the optimal temperature) would have costs. Therefore isotherms at $\mathrm{pH} 5$ and $20^{\circ} \mathrm{C}$ were performed in order to compare it with the optimal conditions. They were also compared with the ones obtained at $\mathrm{pH} 7$, at $20^{\circ} \mathrm{C}$, which correspond to the characteristics expected after a biological treatment and before the sorption polishing treatment. The experimental results of the equilibrium isotherms both for the aqueous dyestuff solution and for the effluent are presented in Figure 2, together with the corresponding fits to Langmuir and Freundlich models. Their parameters and statistics are presented 
in Tables 4 and 5 , respectively for 20 and $45^{\circ} \mathrm{C}$. Both Langmuir and Freundlich models could fit the experimental results owing that Fisher's test shows that there is no statistical difference between them. The highest sorbent capacity was obtained for the optimal conditions in aqueous solution, for the concentration range studied $\left(0-70 \mathrm{mg} \mathrm{L}^{-1}\right)$.

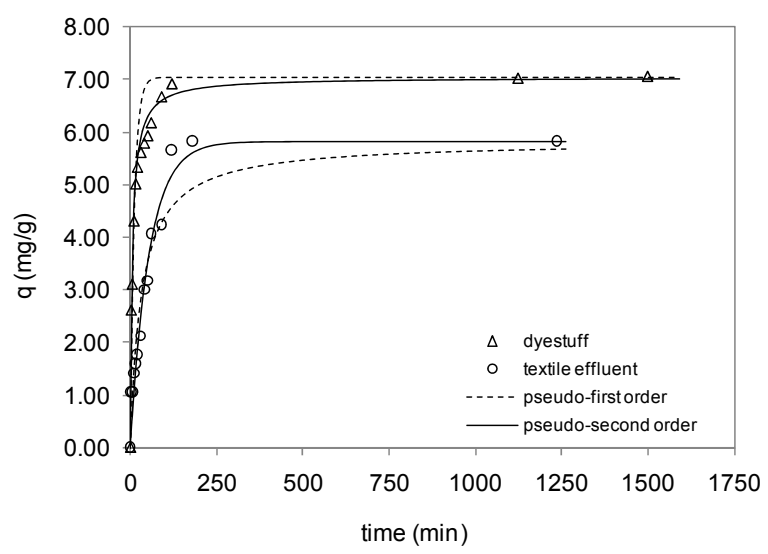

Figure 1. Kinetic studies in DBA dyestuff solution and in the textile effluent; pseudo-first and pseudosecond order models fits, at $\mathrm{pH} 7$ and $20^{\circ} \mathrm{C}$

Table 1. Parameters of the kinetic models for the sorption by feathers of the DBA dyestuff in aqueous solution and in the textile effluent, at $\mathrm{pH} 7$ and $20^{\circ} \mathrm{C}$

\begin{tabular}{llcc}
\hline Model & Parameters & Dyestuff & Textile effluent \\
\hline Pseudo-1 & order $^{\mathrm{st}}\left(\mathrm{min}^{-1}\right)$ & $0.084 \pm 0.03$ & $0.018 \pm 0.003$ \\
& $\mathrm{q}_{\mathrm{e}}\left(\mathrm{mg} \mathrm{g}^{-1}\right)$ & 7.05 & 5.83 \\
$\mathrm{~s}^{2}$ & 0.513 & 0.153 \\
& $\mathrm{r}^{2}$ & 0.939 & 0.968 \\
\hline Pseudo-2 $^{\text {nd }}$ order $\mathrm{k}_{2}\left({\left.\mathrm{~g} \mathrm{(mg} \mathrm{min})^{-1}\right)}\right.$ & $0.023 \pm 0.004$ & $0.005 \pm 0.002$ \\
& $\mathrm{q}_{\mathrm{e}}\left(\mathrm{mg} \mathrm{g}^{-1}\right)$ & 7.05 & 5.83 \\
$\mathrm{~s}^{2}$ & 0.089 & 0.272 \\
$\mathrm{r}^{2}$ & 0.982 & 0.934 \\
\hline
\end{tabular}

Table 2. ANOVA of the quadratic model for DBA dyestuff sorption by feathers

\begin{tabular}{lccccc}
\hline Sources of variation & Degrees of freedom Sum of squares & Mean square & F-ratio & Prob $>$ F \\
\hline Model & 5 & 133.127 & 26.626 & & \\
Error & 14 & 7.531 & 0.538 & 49.497 & $<0.0001$ \\
Corrected total & 19 & 140.658 & & & \\
\hline
\end{tabular}

Table 3. Regression model results for DBA dyestuff sorption by feathers

\begin{tabular}{lrccc}
\hline Term & Coefficient & \multicolumn{1}{c}{ Standard error } & t-ratio & Prob $>|\mathrm{t}|$ \\
\hline Intercept & 4.751 & 0.310 & 15.33 & $<0.0001$ \\
$\mathrm{pH}$ & 2.409 & 0.212 & 11.38 & $<0.0001$ \\
$\mathrm{~T}$ & 1.634 & 0.212 & 7.72 & $<0.0001$ \\
$\mathrm{pH}{ }_{*} \mathrm{~T}$ & 1.365 & 0.259 & 5.26 & 0.0001 \\
$\mathrm{pH}^{2}$ & -0.483 & 0.340 & -1.42 & 0.1765 \\
$\mathrm{~T}^{2}$ & 1.875 & 0.340 & 5.52 & $<0.0001$ \\
\hline
\end{tabular}

The capacities here obtained might also be compared with the ones obtained for other classes of dyestuffs using hen feathers pre-treated by $30 \%(\mathrm{~m} / \mathrm{v})$ hydrogen peroxide during $24 \mathrm{~h}(0.1 \mathrm{~mm}$ 
average grain size). Isotherms at $50^{\circ} \mathrm{C}$ were determined for this material. The capacities presented for Acid red 41 (Gupta et al., 2006), Malachite green (Mittal, 2006a) and Brilliant Blue FCF (Mittal, $2006 \mathrm{~b}$ ), respectively $20.8,27.1$ and $30.9 \mathrm{mg} \mathrm{g}^{-1}$, are lower than the maximum (optimal conditions) obtained in this work, $47 \pm 4 \mathrm{mg} \mathrm{g}^{-1}$.

The $\mathrm{pH}$ showed a slight decrease during the experiments. The maximum variation was observed for the dyestuff aqueous solution (from 5.0 to 4.5).
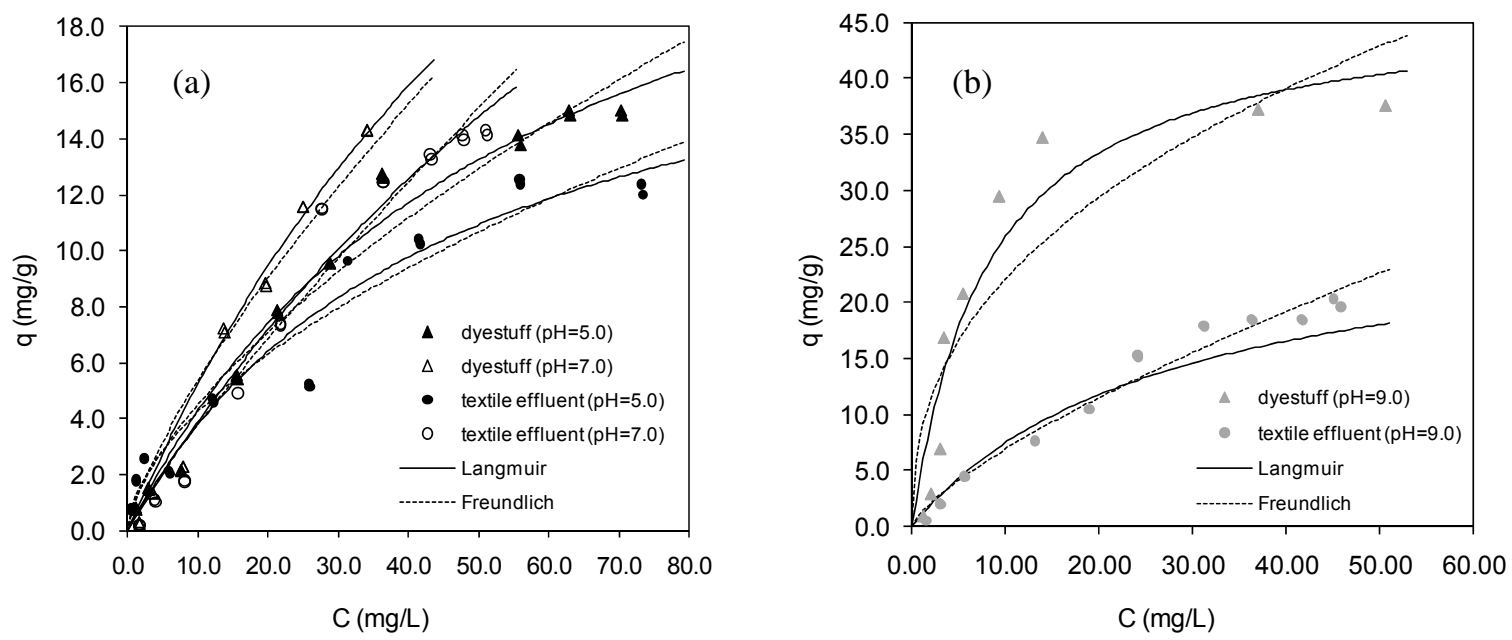

Figure 2. Equilibrium studies for feathers in DBA dyestuff solution and in the textile effluent at $20^{\circ} \mathrm{C}(\mathrm{a})$ and $45^{\circ} \mathrm{C}(\mathrm{b})$; Langmuir and Freundlich models fits

\subsection{Column studies}

The fixed bed column experiments were performed at $20^{\circ} \mathrm{C}$, at $\mathrm{pH} 5,7$ and 9 . The experimental results for the dyestuff both in aqueous solution and in textile effluent are presented in Figure 3 , together with Yoon-Nelson (1984), Thomas (1944) and Yan's (Yan et al., 2001) model fits. Their parameters and statistics are presented in Tables 6 and 7, respectively for the dyestuff in aqueous solution and in the real effluent. In general, both models fitted well the experimental results. According to Fisher's test there is no statistical difference between them, expect for the real effluent at $\mathrm{pH} 9$ for which Yan's model is the best fit. The highest breakthrough time for $50 \%$ removal, $170 \mathrm{~min}$ (estimated by Yoon-Nelson's model), and the highest sorbent capacity, $15 \pm 1 \mathrm{mg} \mathrm{g}^{-1}$ (estimated by Thomas's model), were obtained at $\mathrm{pH} 9$ for the aqueous solution. As expected this capacity, at $20^{\circ} \mathrm{C}$, is lower than in equilibrium studies performed at the optimal temperature, $45^{\circ} \mathrm{C}$.

Table 4. Parameters of the Langmuir and Freundlich models for the sorption of feathers in DBA dyestuff solution and in the textile effluent, at $20^{\circ} \mathrm{C}$

\begin{tabular}{lcccc} 
& \multicolumn{2}{c}{ Dyestuff } & \multicolumn{2}{c}{ Textile effluent } \\
\cline { 2 - 5 } Parameters & $\mathrm{pH}=5.0$ & $\mathrm{pH}=7.0$ & $\mathrm{pH}=5.0$ & $\mathrm{pH}=7.0$ \\
\hline $\mathrm{q}_{\mathrm{m}}\left(\mathrm{mg} \mathrm{g}^{-1}\right)$ & $28 \pm 5$ & $50 \pm 19$ & $21 \pm 7$ & $50 \pm 34$ \\
$\mathrm{~K}_{\mathrm{L}}\left(\mathrm{L} \mathrm{mg}^{-1}\right)$ & $0.018 \pm 0.006$ & $0.012 \pm 0.007$ & $0.02 \pm 0.02$ & $0.008 \pm 0.007$ \\
$\mathrm{~s}^{2}$ & 0.5822 & 2.203 & 1.429 & 1.030 \\
$\mathrm{r}^{2}$ & 0.982 & 0.969 & 0.941 & 0.973 \\
\hline $\mathrm{K}_{\mathrm{F}}\left(\left(\mathrm{mg} \mathrm{g}^{-1}\right)\left(\mathrm{L} \mathrm{mg}^{-1}\right)^{1 / \mathrm{h}}\right)$ & $1.0 \pm 0.4$ & $0.9 \pm 0.5$ & $1.1 \pm 0.5$ & $0.5 \pm 0.3$ \\
$\mathrm{n}$ & $1.5 \pm 0.3$ & $1.3 \pm 0.3$ & $1.7 \pm 0.4$ & $1.2 \pm 0.2$ \\
$\mathrm{~s}^{2}$ & 1.151 & 3.3166 & 1.2868 & 1.3040 \\
$\mathrm{r}^{2}$ & 0.966 & 0.951 & 0.938 & 0.963 \\
\hline
\end{tabular}

\subsection{Comparison with the real effluent}

Equilibrium studies (Figure 2) show that the presence of the dyeing agents in the real effluent decreased the sorption of the dyestuff mostly for $\mathrm{pH} 9$ and $45^{\circ} \mathrm{C}$ (optimal conditions); this difference is not so marked at $20^{\circ} \mathrm{C}$, for $\mathrm{pH} 5$ and 7 . 
Table 5. Parameters of the Langmuir and Freundlich models for the sorption of feathers in DBA dyestuff solution and in the textile effluent, at $\mathrm{pH} 9$ and $45^{\circ} \mathrm{C}$

\begin{tabular}{lcc} 
& Dyestuff & Textile effluent \\
\hline $\mathrm{q}_{\mathrm{m}}\left(\mathrm{mg} \mathrm{g}^{-1}\right)$ & $47 \pm 8$ & $28 \pm 10$ \\
$\mathrm{~K}_{\mathrm{L}}\left(\mathrm{L} \mathrm{mg}^{-1}\right)$ & $0.13 \pm 0.06$ & $0.04 \pm 0.03$ \\
$\mathrm{~s}^{2}$ & 20.9 & 3.822 \\
$\mathrm{r}^{2}$ & 0.920 & 0.979 \\
\hline $\mathrm{K}_{\mathrm{F}}\left(\left(\mathrm{mg} \mathrm{g}^{-1}\right)\left(\mathrm{L} \mathrm{mg}^{-1}\right)^{1 / n}\right)$ & $9 \pm 4$ & $1.3 \pm 0.5$ \\
$\mathrm{n}$ & $2.4 \pm 0.8$ & $1.4 \pm 0.2$ \\
$\mathrm{~s}^{2}$ & 48.49 & 1.587 \\
$\mathrm{r}^{2}$ & 0.787 & 0.973 \\
\hline
\end{tabular}

The breakthrough curves (Figure 3 ) at $20^{\circ} \mathrm{C}$ for $\mathrm{pH} 5$ and 7 do not show significant differences for the dyestuff both in aqueous solution and in the real effluent. Only at $\mathrm{pH} 9$ a significant difference is observed for the dyestuff solution. Since there is no significant effect of the $\mathrm{pH}$, the real effluent could be treated in a more economical way at the original $\mathrm{pH}$ (or $\mathrm{pH} \mathrm{7,} \mathrm{if} \mathrm{there} \mathrm{is} \mathrm{a} \mathrm{biological}$ treatment), without $\mathrm{pH}$ adjustment. Given that the optimization studies show that temperature has a minor effect than $\mathrm{pH}$, then it would also have little influence in the treatment the textile effluent.
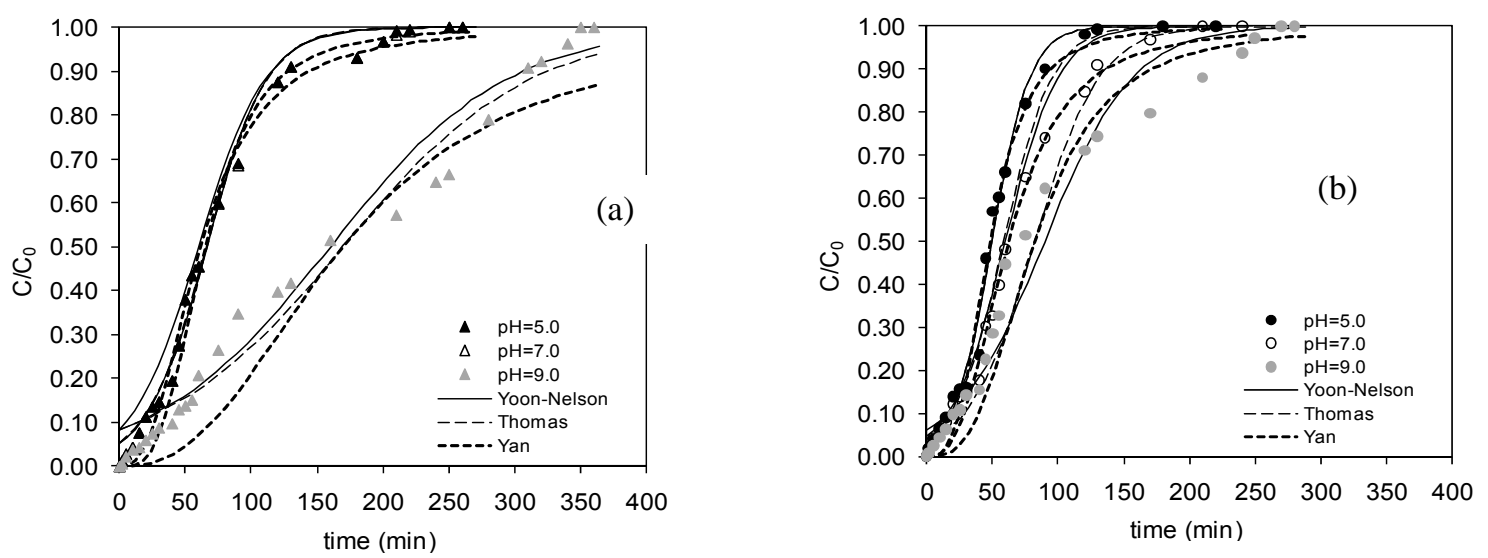

Figure 3. Column studies, at $20^{\circ} \mathrm{C}$, for DBA dyestuff sorption by feathers in aqueous solution (a) and in the textile effluent (b); Yoon-Nelson, Thomas and Yan's model fits

Table 6. Parameters of the column models for the sorption by feathers in DBA dyestuff aqueous solution, at $20^{\circ} \mathrm{C}$

\begin{tabular}{llccc}
\hline Model & Parameters & $\mathrm{pH}=5$ & $\mathrm{pH}=7$ & $\mathrm{pH}=9$ \\
\hline Yoon-Nelson & $\mathrm{k}_{\mathrm{YN}}\left(\mathrm{min}^{-1}\right)$ & $0.044 \pm 0.005$ & $0.044 \pm 0.005$ & $0.015 \pm 0.002$ \\
$(\mathrm{YN})$ & $\mathrm{T}_{\mathrm{YN}}(\mathrm{min})$ & $66 \pm 3$ & $67 \pm 3$ & $170 \pm 12$ \\
& $\mathrm{~s}^{2}$ & 0.0012 & 0.0013 & 0.0036 \\
& $\mathrm{r}^{2}$ & 0.994 & 0.993 & 0.974 \\
\hline Thomas & $\mathrm{k}_{\mathrm{TH}}\left(\mathrm{mL}^{2}\left(\mathrm{mg} \mathrm{min}^{-1}\right)\right.$ & $0.62 \pm 0.07$ & $0.62 \pm 0.07$ & $0.21 \pm 0.03$ \\
$(\mathrm{~T})$ & $\mathrm{q}_{\mathrm{TH}}\left(\mathrm{mg} \mathrm{g}^{-1}\right)$ & $5.9 \pm 0.2$ & $5.9 \pm 0.3$ & $15 \pm 1$ \\
& $\mathrm{~s}^{2}$ & 0.0012 & 0.0013 & 0.0035 \\
& $\mathrm{r}^{2}$ & 0.994 & 0.993 & 0.974 \\
\hline Yan & $\mathrm{a}_{\mathrm{Y}}$ & $2.6 \pm 0.3$ & $2.6 \pm 0.3$ & $2.0 \pm 0.4$ \\
$(\mathrm{Y})$ & $\mathrm{q}_{\mathrm{Y}}\left(\mathrm{mg} \mathrm{g}^{-1}\right)$ & $5.5 \pm 0.1$ & $5.5 \pm 0.3$ & $12 \pm 2$ \\
& $\mathrm{~s}^{2}$ & 0.0011 & 0.0011 & 0.0047 \\
& $\mathrm{r}^{2}$ & 0.995 & 0.995 & 0.967 \\
\hline
\end{tabular}


Table 7. Parameters of the column models for the sorption by feathers of the DBA dyestuff in the textile effluent, at $20^{\circ} \mathrm{C}$

\begin{tabular}{llccc}
\hline Model & Parameters & $\mathrm{pH}=5$ & $\mathrm{pH}=7$ & $\mathrm{pH}=9$ \\
\hline Yoon-Nelson & $\mathrm{k}_{\mathrm{YN}}\left(\mathrm{min}^{-1}\right)$ & $0.070 \pm 0.009$ & $0.046 \pm 0.006$ & $0.031 \pm 0.006$ \\
$(\mathrm{YN})$ & $\mathrm{T}_{\mathrm{YN}}(\mathrm{min})$ & $50 \pm 2$ & $65 \pm 3$ & $83 \pm 8$ \\
& $\mathrm{~s}^{2}$ & 0.0013 & 0.0011 & 0.0042 \\
& $\mathrm{r}^{2}$ & 0.992 & 0.993 & 0.975 \\
\hline Thomas & $\mathrm{k}_{\mathrm{TH}}\left(\mathrm{mL}^{2}\left(\mathrm{mg} \mathrm{min}^{-1}\right.\right.$, & $1.0 \pm 0.2$ & $0.68 \pm 0.08$ & $0.45 \pm 0.09$ \\
$(\mathrm{~T})$ & $\mathrm{q}_{\mathrm{TH}}\left(\mathrm{mg} \mathrm{g}^{-1}\right)$ & $4.6 \pm 0.2$ & $5.6 \pm 0.3$ & $7.1 \pm 0.7$ \\
& $\mathrm{~s}^{2}$ & 0.0013 & 0.0011 & 0.0042 \\
& $\mathrm{r}^{2}$ & 0.992 & 0.993 & 0.975 \\
\hline Yan & $\mathrm{a}_{\mathrm{Y}}$ & $3.3 \pm 0.6$ & $2.7 \pm 0.4$ & $2.1 \pm 0.2$ \\
$(\mathrm{Y})$ & $\mathrm{q}_{\mathrm{Y}}\left(\mathrm{mg} \mathrm{g}^{-1}\right)$ & $4.4 \pm 0.3$ & $5.3 \pm 0.3$ & $6.3 \pm 0.4$ \\
& $\mathrm{~s}^{2}$ & 0.0022 & 0.0015 & 0.0013 \\
& $\mathrm{r}^{2}$ & 0.989 & 0.992 & 0.992 \\
\hline
\end{tabular}

\section{CONCLUSIONS}

The effects over the sorption in aqueous solution of the basic dyestuff Dark Blue Astrazon 2RN by gallinaceous feathers were evaluated for temperature $\left(15-45^{\circ} \mathrm{C}\right)$ and $\mathrm{pH}(5-9)$. The influence of $\mathrm{pH}$ is more significant than temperature and the optimal conditions selected were $45^{\circ} \mathrm{C}$ and $\mathrm{pH} 9$.

Equilibrium studies in the concentration range selected $\left(0-70 \mathrm{mg} \mathrm{L}^{-1}\right)$ show that the highest sorbent capacity was obtained at the optimal conditions for the dyestuff in aqueous solution, which corresponds to a maximum capacity of $47 \pm 4 \mathrm{mg} \mathrm{g}^{-1}$.

In column studies the highest breakthrough time for $50 \%$ removal, $170 \mathrm{~min}$, and the highest sorbent capacity, $15 \pm 1 \mathrm{mg} \mathrm{g}^{-1}$, were obtained at $\mathrm{pH} 9$ and $20^{\circ} \mathrm{C}$ for the aqueous solution.

One of challenges in the treatment of real industrial wastewater is their complexity. The presence of the dyeing agents in the real wastewater decreased the sorption of the dyestuff mostly for $\mathrm{pH} 9$, which is the optimal $\mathrm{pH}$. The effect of $\mathrm{pH}$ is less pronounced in the real effluent than in aqueous solution of the dyestuff and not significant in column experiments. Given that temperature had also shown minor effect than $\mathrm{pH}$ the effluent may be treated more economically at its original $\mathrm{pH}$ and temperature. This work shows that feathers are a promising sorbent for DBA effluents.

\section{REFERENCES}

Anliker R., Drig G., Steinle D. and Moriconi E.J., (1988), List of colorants to be classified as toxic, J. S. D. C., 104, 223-225.

Bailey S.E., Olin T.J., Bricka M. and Adrian D.D., (1999), A review of potentially low-cost sorbents for heavy metals, Water Res., 33, 2469-2479.

Crini G., (2006), Non-conventional low-cost adsorbents for dye removal: A review, Bioresour. Technol., 97, 1061-1085.

Dystar (2002) URL: http://www2.dystar.com/idx/material safety data sheet.htm (accessed 24/03/2011).

El Qada E.N., Allen S.J. and Walker G.M., (2008), Adsorption of basic dyes from aqueous solution onto activated carbons, Chem. Eng. J., 135, 174-184.

Fiber Economics Bureau (2003) URL: http://www.fibersource.com/f-info/fiber\%20production.htm (accessed 24/03/2011).

Freundlich H.M.F., (1906), Über die adsorption in läsungen, Zeitschrift fur Physikalische Chemie, 57, 385470.

Gupta V.K. and Suhas, (2009), Application of low-cost adsorbents for dye removal - A review, J. Environ. Manage., 90, 2313-2342.

Gupta V.K., Mittal A., Kurup L., Mittal J., (2006), Adsorption of a hazardous dye, erythrosine, over hen feathers, J. Colloid Interface Sci., 304, 52-57.

Ho Y.S., (1995), Absorption of heavy metals from waste streams by peat, Ph.D. Thesis, University of Birmingham, UK. 
Lagergren S., (1898), Zur theorie der sogenannten adsorption gelöster stoffe, K. Sven. Vetenskapsakad. Handl., 24(4), 1-39.

Langmuir I., (1918), The adsorption of gases on surface of glass, mica and platinum, J. Am. Chem. Soc., 40, 1361-1403.

McKay G., Blair H.S., Gardner J., (1982), Adsorption of dyes on chitin. I. Equilibrium studies, J. Appl. Polym. Sci., 27, 3043-3057.

Mittal A., (2006a), Adsorption kinetics of removal of a toxic dye, Malachite Green, from wastewater by using hen feathers, J. Hazard. Mater., 133, 196-202.

Mittal A., (2006b), Use of hen feathers as potential adsorbent for the removal of a hazardous dye, Brilliant Blue FCF, from waste water, J. Hazard. Mater., 128, 233-239.

Mittal A., Mittal J. and Kurup L., (2007), Utilization of Hen Feathers for the Adsorption of Indigo Carmine from Simulated Effluents, J. Environ. Prot. Sci., 1, 92-100.

Noh J.S., Schwarz J.S., (1991), Relationship between metal ion adsorption and catalytic properties of carbon-supported nickel catalysts, J. Catal., 127(1), 22-33.

Srinivasan A., Viraraghavan T., (2010), Decolorization of dye wastewaters by biosorbents: A review, J. Environ. Manage., 91, 1915-1929.

Thomas H.C., (1944), Heterogeneous ion exchange in a flowing system, J. Am. Chem. Soc., 66, 16641666.

Yan G., Viraraghavan T. and Chen M., (2001), A new model for heavy metal removal in biosorption column, Adsorpt. Sci. Technol., 19, 25-43.

Yoon Y.H. and Nelson J.H., (1984), Application of gas adsorption kinetics. I. A theoretical model for respirator cartridge service time, Am. Ind. Hyg. Assoc. J., 45, 509-516. 